\title{
CHARACTERISTICS OF PHYSICAL ACTIVITY AMONG HEALTHY SERBIAN ADOLESCENTS
}

\author{
CARACTERISTICAS DA ATIVIDADE FISICA DE ADOLESCENTES SÉRVIOS SAUDÁVEIS
}

Original Article

CARACTERISTICAS DE LAACTIVIDAD FÍSICA DE ADOLESCENTES SERBIOS SALUDABLES

Artigo OrigINAL

Artículo Original

\begin{abstract}
Maja Nikolić (D)
(Physician)

Radmila Jovanović ${ }^{2}$ (ID

(Physician)

Aleksandra Stanković ${ }^{1}$ (DD

(Physician)

1. University of Niš, Faculty of medicine, Department of Social medicine and hygiene with medical ecology, Niš, Serbia.

2. Public health Center, Department of hygiene, Pančevo, Serbia.
\end{abstract}

\section{Correspondence:}

Maja Nikolić. Sindjelicev trg 18///18, 18000 Nis, Serbia.

mani@junis.ni.ac.rs

\begin{abstract}
Introduction: Physical activity (PA) remains the most important modifiable risk factor in the prevention of chronic diseases that are major killers in the modern era. However, many young people today do not meet the recommended guidelines on PA. Few studies were found on the levels of physical activity among adolescents from transitional countries. Objective: To determine the levels of physical activity in a representative sample of healthy adolescents from Pančevo (Serbia), and the factors that determine these level. Methods: This cross-sectional study included 401 randomly selected adolescents (191 boys and 210 girls) from the city of Pančevo, Serbia. The long version of the International Physical Activity Questionnaire (IPAQ), validated for Serbia, was applied. PA was expressed as metabolic equivalent-minute per week (MET-min/week) and classified as low, moderate, or high. Results: The median PA for the whole sample was 2049.18 MET-min/week. The average PA score in boys was higher (2680 MET-min/week) than in girls (1479 MET-min/week). The prevalence of respondents with inadequate PA was 53.9\%, and was higher in girls than in boys. Boys showed the higher values for intense and moderate PA, while the prevalent type of PA among girls was walking. Level of PA did not depend on the adolescent's nutritional status. The most important predictors of PA among the participants were sex, father's PA, and hours spent on sedentary activities like using a computer and watching television. Conclusion: Adolescents in Pančevo do not practice enough physical activity, especially girls. Better strategies are needed, to increase levels of PA, considering the main predictors in the adolescent population. Level of Evidence Il; Retrospective study.
\end{abstract}

Keywords: Physical activity; Adolescent; Epidemiology.

\section{RESUMO}

Introdução: A atividade física (AF) continua sendo o fator de risco modificável mais importante na prevenção de doenças crônicas, conhecidas como principais causadoras de morte na era moderna. No entanto, atualmente, muitos jovens não estão atendendo às diretrizes de AF. Poucos estudos sobre o nível de atividade física foram encontrados nas amostras de adolescentes dos países em transição. Objetivo: Determinar o nível de atividade fisica de uma amostra representativa de adolescentes saudáveis de Pančevo (Sérvia), assim como os fatores de condicionamento desse nivel. Métodos: O estudo retrospectivo incluiu 401 adolescentes selecionados aleatoriamente (191 meninos e 210 meninas) da cidade de Pančevo, Sérvia. Aplicou-se a versão sérvia longa e validada do International Physical Activity Questionnaire (IPAQ). A AF foi expressa através do equivalente metabólico - minuto por semana (MET-min/semana) e classificada em baixa, moderada e alta. Resultados: A mediana da AF total para toda a amostra foi de 2049,18 MET-min/semana. O escore total médio de AFobservado nos meninos foi maior (2680 MET-min/semana) do que nas meninas (1479 MET-min/semana). A prevalência de respondentes ativos não adequados foi de 53,9\%, maior número de meninas do que meninos. O grupo de participantes do sexo masculino apresentou os maiores valores de escore intensivo e moderado de AF, enquanto o tipo de AF dominante entre as meninas foi a caminhada. O nível de AF não dependeu do estado nutricional dos adolescentes. Os preditores mais importantes da AF entre os participantes foram sexo, AF do pai e horas de atividades sedentárias, como por exemplo, usar o computador ou assistir televisão. Conclusão: Os adolescentes em Pančevo não praticavam atividade física o suficiente, especialmente, as meninas. É necessário desenvolver melhores estratégias para garantir o aumento da AF com atenção aos principais preditores na população de adolescentes. Nível de evidência Il; Estudos retrospectivo.

Descritores: Atividade física; Adolescente; Epidemiologia.

\section{RESUMEN}

Introducción: La actividad física (AF) continúa siendo el factor de riesgo modificable más importante en la prevención de enfermedades crónicas, conocidas como principales causadoras de muerte en la era moderna. Sin embargo, actualmente, muchos jóvenes no están atendiendo las directrices de AF. Pocos estudios sobre el nivel de actividad física fueron encontrados en las muestras de adolescentes de los países en transición. Objetivo: Determinar el nivel de actividad física de una muestra representativa de adolescentes saludables de Pančevo (Serbia), así como los factores de condicionamiento de ese nivel. Métodos: El estudio retrospectivo incluyó a 401 adolescentes seleccionados aleatoriamente (191 niños y 210 niñas) de la ciudad de Pančevo, Serbia. Se aplicó la versión serbia larga y validada del 
International Physical Activity Questionnaire (IPAQ). La AF fue expresada a través del equivalente metabólico-minuto por semana (MET-min/semana) y clasificada en baja, moderada y alta. Resultados: El promedio de AF total para toda la muestra fue de 2049,18 MET-min/semana. El puntaje total promedio de AF observado en los niños fue mayor (2680 MET-min/semana) que en las niñas (1479 MET-min/semana). La prevalencia de respondientes activos no adecuados fue de 53,9\%, mayor número de niñas que de niños. El grupo de participantes del sexo masculino presentó los mayores valores de puntaje intensivo y moderado de AF, mientras que el tipo de AF dominante entre las niñas fue la caminata. El nivel de AF no dependió del estado nutricional de los adolescentes. Los predictores más importantes de AF entre los participantes fueron sexo, AF del padre y horas de actividades sedentarias como, por ejemplo, usar la computadora 0 ver televisión. Conclusión: Los adolescentes en Pančevo no practicaban suficiente actividad física, especialmente las niñas. Es necesario desarrollar mejores estrategias para garantizar el aumento de la AF con atención a los principales predictores en la población de adolescentes. Nivel de evidencia Il; Estudio retrospectivo.

Descriptores: Atividad física; Adolescente; Epidemiología.

\section{INTRODUCTION}

Inadequate physical activity (PA), combined with an unhealthy diet, is a modifiable risk factor for many chronic diseases, including cardiovascular disease, type 2 diabetes, obesity, hypertension, some type of cancer and depression ${ }^{1-3}$. Physical activity has also therapeutic effects across several diseases and conditions.

The health benefits of regular exercise and physical activity are independent of age, but it is especially important for young people. The level of PA among children and adolescents is an important premise for their present and future health promoting life style, that is emphasized in many studies ${ }^{4-7}$. Regular physical activity helps in the prevention and control of risk behaviors such as smoking, alcohol consumption and abuse of psychoactive substances, and it impacts on diet and prevents violence ${ }^{8}$. Together with sports, it promotes psychological well-being and reduce stress, anxiety, depression and loneliness.

However, a recent worldwide survey revealed that large proportions of young people across different European countries did not meet PA recommendations (60 minutes or more in moderate physical activity on five or more days a week, totalizing at least 300 minutes of physical activity per week) and spent a lot of time sedentary.According to data from five European countries ${ }^{9}$, only $4.6 \%$ of girls and $16.8 \%$ of boys complied with the $60 \mathrm{~min} /$ day of moderate- to vigorous-intensity physical activity daily. Generally speaking, citizens of southern EU countries have lower levels of PA than northern and western countries ${ }^{10}$. Additionaly, PA level declines across the lifespan, particularly during adolescence ${ }^{11}$.

In most transitional countries, significant deviations from recommendations for healthy lifestyle was noted in childrens' habits, knowledge and practice ${ }^{12-14}$. Furthermore, a change in diet and sedentary lifestyle has been reflected in an increase of the number of overweight and obese children ${ }^{15}$. Measuring and assessing physical activity in childhood and the period of adolescence are important for the regulation of body weight, and they give important information on health potential as well.

Our aim was to determine the level of physical activity of a representative sample of adolescents from Pančevo, as well as the factors conditioning this level.

\section{MATERIALS AND METHODS}

The data were derived from a cross-sectional study conducted in Pančevo (South Banat District, north east part of Serbia). According to the last official census from 2002, there were 6625 children (3366 boys and 3259 girls) in Pančevo city ( 84.702 inhabitants). A total of 401 subjects (191 boys and 210 girls, 15-17 years of age) were selected using simple random sampling from five secondary schools located in the city of Pančevo, that represent more than 5\% sample. The sample did not include pupils who lived in collective institutions.
Upon the obtained permission of the Ministry of education and science Republic of Serbia, the headmasters of the schools were informed of the research. Parents and pupils were informed about the purpose of the study and the participants had the opportunity to end the physical activity monitoring at any time. If both the parents and the pupil agreed to take part in the research, they signed an informed consent. The authors also followed the World Medical Association's Declaration of Helsinki.

The distribution of the questionnaires and collection of the responses were at school. The first part of questionnaire contained questions provide information on socio-demographic data (age, gender of participant, place of living etc.). The long version of the Physical Activity Questionnaire (IPAQ) was applied ${ }^{16}$. The IPAQ is a self-administered questionnaire and originally developed for adults between 15-69 years, consists of 27 questions that cover assessing the four domains of PA (leisure time physical activity, domestic and gardening activities, work-related physical activity and transport-related physical activity). To adapt the questionnaire to the young population, questions about PA at work were replaced by questions about PA at school. Furthermore, the items relating domestic and gardening PA were reduced to one question. All questions refer to the previous 7 days. The results of the IPAQ questionnaire were processed in accordance with the officially recommended "Guidelines for data processing and analysis of the international physical activity questionnaire"16. PA was expressed a metabolic equivalent-minute per week (MET-min/ week). METmin/week score of specific activity is computed MET value of particular activity with time spent in particular activity. Total PA score was calculated, as well as separate scores for each of the 4 domains. The MET values PA levels were classified as low level (<600MET-min/week), moderate level of activity (600-1500MET/-min/week) and adequate - high (>1500MET-min/week) and very high (>3000MET-min/week).

The questionnaire validity was first tested in other serbian adolescents (using the IPAQ procedure) and conspicuous correlations between PA reported in the questionnaire and pedometer measured PA were found ${ }^{17}$.

Anthropometric parameters were collected in all participants. Body weight $(\mathrm{kg})$ was measured to the nearest $0.01 \mathrm{~kg}$ using a balance scale. Height (m) was measured using a stadiometer to the nearest $0.01 \mathrm{~m}^{18}$. Body mass index (BMI) was calculated using the formula weight/height ${ }^{2}\left(\mathrm{~kg} / \mathrm{m}^{2}\right)$.

Standard descriptive statistical methods were used for data analysis. The result osbtained are presented in tables and figures. Data were analyzed using SPSS package version 15 with significance level set at $p<0.05$.

\section{RESULTS}

Of the 407 adolescents, after excluding 6 pupils not willing to participate, 401 gave initial consent (response rate 98.5\%) and majority were female (52.4\%). Mean age of participants was 16.5 (SD \pm 1.9 years) for 
boys and 16.7 (SD \pm 1.7 years) for girls. There was no statistically significant difference in boys' age compared to girls $(p=0.661)$ Table 1 .

The median of total PA for the whole sample was 2049.2 MET-min/ week (Table 2). The average total PA score (Figure 1) observed in boys ( 2680.6 MET-min/week) was significantly higher than in girls -1478.9 MET-min/week ( $t=6.319, p<0.0001)$.

This study found that prevalence of non adequate active respondents was $53.9 \%$, and prevalence of active was $79.8 \%$ (Table 2). Adequate PA level was found in $46.1 \%$ of participants. Among 81 inactive adolescents, 55 was girls and 26- boys.

The types of PA among adolescents in the study was different regarding sex. The male participants showed the higher values of intensive and moderate PA score compared to female and dominant type of PA among girls was walking (Table 3 ).

Examined adolescents were physically very active at leisure-time domain and in the domestic and garden domain as opposed to transportation (Table 4). The boys and girls in the study differed statistically by all domains of PA, except transport.

In the regression model with PA as dependent variable, we used independent variables from the study those are in previous statistical tests

Table 1. Baseline characteristics of the adolescents.

\begin{tabular}{c|c|c|c|c}
\hline Characteristic & $\begin{array}{c}\text { Boys }(\mathbf{n}=191) \\
\text { mean } \pm \text { SD }\end{array}$ & $\begin{array}{c}\text { Girls }(\mathbf{n}=\mathbf{2 1 0}) \\
\text { mean } \pm \text { SD }\end{array}$ & $\mathbf{t}^{*}$ & $\mathbf{p}$ \\
\hline Age (years) & $16.5 \pm 1.9$ & $16.7 \pm 1.7$ & 0.828 & 0.661 \\
\hline Body height $(\mathrm{cm})$ & $179.1 \pm 8.2$ & $165.9 \pm 6.7$ & 17.710 & 0.000 \\
\hline Body weight $(\mathrm{kg})$ & $72.5 \pm 14.0$ & $60.6 \pm 9.8$ & 9.752 & 0.000 \\
\hline Body mass index $(\mathrm{kg} / \mathrm{m} 2)$ & $22.5 \pm 4.0$ & $21.9 \pm 3.0$ & 1.615 & 0.107 \\
\hline
\end{tabular}

*Student t-test

Table 2. The category of participants according to the level of PA.

\begin{tabular}{c|c|c}
\hline Total level of PA measured using IPAQ & $\begin{array}{c}\text { Participants } \\
\mathbf{N}(\%)\end{array}$ & $\begin{array}{c}\text { MET-min/week } \\
\text { (mean } \pm \text { SD) }\end{array}$ \\
\hline Very low level of activity & $81(20,2)$ & $486.6 \pm 137.9$ \\
\hline Low level of activity & $135(33,7)$ & $1180.2 \pm 920.5$ \\
\hline Moderate level of activity & $109(27,2)$ & $2083.8 \pm 387.6$ \\
\hline Very high level of activity & $76(18,9)$ & $5167.4 \pm 2059.76$ \\
\hline Total & $401(100)$ & $2049.2 \pm 1935.5$ \\
\hline
\end{tabular}

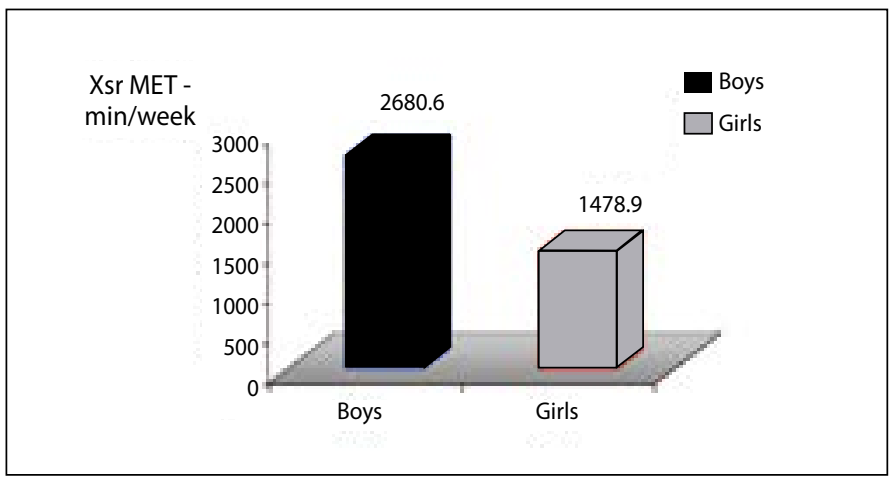

Figure 1. The level of PA among participants measured using IPAQ.

Table 3. Types of PA according to sex.

\begin{tabular}{c|c|c|c}
\hline Type of activity & $\begin{array}{c}\text { MET-min/week } \\
(\text { mean } \pm \text { SD) }\end{array}$ & $t^{*}$ & $p$ \\
\hline $\begin{array}{c}\text { walking } \\
\text { (male/female) }\end{array}$ & $720.2 \pm 709.1 / 639.9 \pm 504.1$ & 1.136 & $>0.05$ \\
\hline $\begin{array}{c}\text { moderate PA } \\
\text { (male/female) }\end{array}$ & $1010.6 \pm 709.1 / 478.9 \pm 355.3$ & 6.046 & $<0.0001$ \\
\hline $\begin{array}{c}\text { Intensive PA } \\
\text { (male/female) }\end{array}$ & $949.7 \pm 714.1 / 360.9 \pm 157.6$ & 4.607 & $<0.0001$ \\
\hline **Student t-test.
\end{tabular}

differ significantly like: gender, level of mother's PA, level of father's PA, floor of housing of adolescents, elevator using, family income, smoking habits, alcohol consuming, drug consuming, TV/hours and PC/hours.

Multiple regression analyses showed that the most important predictors of PA among adolescents that remained significant were gender, PA of father and hours of sedentary activities like PC using and TV watching (Table 5).

Table 4. The level of PA of different domain.

\begin{tabular}{c|c|c|c}
\hline Domain & $\begin{array}{c}\text { MET-min/week } \\
(\mathbf{m e a n} \pm \text { SD) }\end{array}$ & $\mathbf{t}^{*}$ & $\mathbf{p}$ \\
\hline School(male/female) & $209.0 \pm 84.6 / 168.9 \pm 96.8$ & 4.400 & $<0.0001$ \\
\hline Transport(male/female) & $141.5 \pm 89.3 / 149.1 \pm 82.9$ & 0.289 & $>0.5$ \\
\hline Domestic and garden (male/female) & $755.2 \pm 109.9 / 312.5 \pm 97.09$ & 5.298 & $<0.0001$ \\
\hline Leisure-time(male/female) & $1574.9 \pm 966.2 / 848.4 \pm 807.1$ & 4.674 & $<0.0001$ \\
\hline
\end{tabular}

Table 5. Model of logistic regression - statistically significant variables.

\begin{tabular}{c|c|c|c|c}
\hline Variable & $\mathbf{B}^{*}$ & Standard error & $\mathbf{t}$ & P value \\
\hline PA of father & 0,144 & 0,068 & 2,113 & 0.000 \\
\hline Watching TV/hours & $-0,257$ & 0,066 & $-3,878$ & 0.035 \\
\hline Working on PC/hours & 0.0095 & 0,037 & $-2,546$ & 0.000 \\
\hline Gender(male\#) & $-0,615$ & 0,096 & $-6,391$ & 0.011 \\
\hline
\end{tabular}

* regression coefficient. \# reference category.

\section{DISCUSSION}

Understanding of the faulty PA habits and the factors responsible is very essential to develop effective interventions for PA promotion and minimiying life style problems like obesity during adolescence.

In this study total PA in the representative sample of adolescents from one area in Serbia was almost 2700 MET-min/week for boys and about $1500 \mathrm{MET}$-min/week for girls. Majority of the respondents reach the level of at least 30 minutes of moderate PA or a 1,5 hour of vigorous PA five days of week. Only about 19\% of Serbian adolescent are characterized by a high level of physical activity, which was less that reported in the study done in other European countries. In a study done in Poland, more than $60 \%$ of adolescents had high level of $\mathrm{PA}^{19}$. The results of the study done in Ukraine ${ }^{20}$ showed that the mean total physical activity of students was 3.560 MET-min/week. The majority of 17-year-old adolescents attending selected schools in Lithuania characterized by a high level of physical activity close to 5000 MET-min/week ${ }^{21}$, with the larger group being boys. On the other hand, most other recently studies dealing with physical activity among European adolescents conclude that interventions to enhance physical activity are strongly needed 22-24.

Our survey also obtained the gender differences whereby boys were significantly more active than girls. This result is in accordance with many previous studies ${ }^{25,26}$. According to Sallise et al. ${ }^{26}$, differences in PA between genders mainly start appearing at 16 years old. The study of Vasickova et al. ${ }^{27}$ suggested that well-designed type of intervention into the PA behavior of adolescents could eliminate differences in PA among girls and boys. Some studies suggest that gender differences are caused by biological differences and even hormonal changes between girls and boys and other believe that difference in socialization in which girls are encouraged to be more focused on their own emotions and the analysis of them often leads to sedentary behaviour.

For a more complete insight into the pattern of physical activity, it is interesting to separately analyze each physical activity domain. Our study showed that among girls dominates activities related with walking, while among boys intensive activity dominated. Also Bergier et al. ${ }^{21}$ reported similar findings. Armstrong and Welsman ${ }^{28}$ state that European boys are more active than European girls, particularly in term of vigorous PA. 
It was also found that adolescents who more lead a sedentary style of life (large time spent sitting in front of PC orTV) are characterized by a lower level of total PA. Using PC among youth for chatting on-line, internet, emailing, homework etc. in their free time has increased markedly in the last years and played an important role in influencing their PA level. Our findings also highlight a need for strategies and interventions aimed at reducing screen-time behaviours and promoting moderate-to-vigorous physical activity.

In our study, the distribution of physical activity throughout domains indicated considerably lower physical activity of adolescents in the domains of transport than in the domains of leisure -time and garden. The results indicate the importance of creating physical activity interventions with the emphasis on school and transportation domain.Attention should be paid to adolescents attending physical exercise classes at schools.

Some authors pointed out to the importance of parents and their multiple roles influencing youths' physical activity behaviours, such as creating health-promoting rules and serving as a role model for physical activity. Like in many our studies ${ }^{29,30}$, the important predictor of PA among adolescents in our survey was PA of father. For example, regular exercising of both mother and father predicts 13 - 14-year old adolescents' engagement in sport. According to Cheng et al., ${ }^{30}$ physical activity of the father was associated with that of their sons.

The WHO Regional Office for Europe is committed to encouraging and supporting countries to develop and implement their own guidelines. Developing the national guidelines for physical activity is an important part of creating public health policies in transitional countries and disseminating consistent information about a healthy lifestyle.
The major advantages of this study are the methods used. The long version of IPAQ allowed us to determine the level of physical activity in each of 4 physical activity domains, which is very important in order to get a complete insight into the pattern of physical activity among adolescents. But if we want to compare this study with similar studies conducted in other countries, we have to bear in mind that the recent studies in the European Union countries used the short version of IPAQ. Although comparative studies have shown that results obtained by different versions of IPAQ can be compared, physical activity estimated using the long version of IPAQ may be higher because the short version systematically underestimates physical activity level. The results of the study were limited by the local character of research. The sample size and this might make our findings less generalizable. Although Serbia is a typical example of a post-communist country in social and economic transition, generalization of our results on other transitional countries is not completely accurate.

\section{CONCLUSION}

Based on our results, we could conclude that urban adolescents in Serbia do not engage in sufficient physical activity. Gender difference affects the PA level of adolescents, as well as PA of father and sedentary activities. Taking into account these factors, it is necessary to pay greater attention to this population group while developing health programmes to ensure that the PA among adolescents be increased.

All authors declare no potential conflict of interest related to this article

AUTHORS' CONTRIBUTIONS: Each author made significant individual contributions to this manuscript. MN: writing, analysis of the data, revision and performing the surgeries, intellectual concept, and preparation of the whole research project; RJ: writing, analysis of the data, statistical analysis, analysis of the slides, revision and performing the surgeries, intellectual concept and preparation of the whole research project; AS: performed the literature review, revision of the manuscript and contributed to the intellectual concept of the study.

\section{REFERENCES}

1. Nunan D, Mahtani KR, Roberts N, Heneghan C. Physical activity for the prevention and treatment of major chronic disease: an overview of systematic reviews. Syst Rev. 2013;2:56-61.

2. Lee I-M, Shiroma EJ, Lobelo F, Puska P, Blair SN, Katzmarzyk PT. Effect of physical inactivity on major non-communicable diseases worldwide: an analysis of burden of disease and life expectancy. Lancet. 2012;380(9838):219-29.

3. Bielemann RM, Silva BG, Coll CdeV, Xavier MO, Silva SG. Burden of physical inactivity and hospitalization costs due to chronic diseases. Rev Saude Publica. 2015; 49: 75-83.

4. World Health Organization. Global Recommendations on Physical Activity for Health. Geneva; 2010. p. 60.

5. Janssen I, Leblanc AG. Systematic review of the health benefits of physical activity and fitness in school-aged children and youth. Int J BehavNutr Phys Act. 2010;7:40.

6. Dobbins M, Husson H, DeCorby K, LaRocca RL. School-based physical activity programs for promoting physical activity and fitness in children and adolescents aged 6 to 18. Cochrane Database Syst Rev.2013;(2):CD007651.

7. MorínFraile V. Promotion of physical activity.Rev Enferm. 2013;36(1):8-16.

8. LesjakV, Stanojević-Jerković O. Physical Activity, Sedentary Behavior and Substance Use among Adolescents in Slovenian Urban Area. Zdr Varst. 2015;54(3):168-74

9. Verloigne $M$, van Lippevelde W, Maes L, Yildirim M, Chinapaw M, Manios Y, et al. Levels of physical activity and sedentary time among 10- to 12-year-old boys and girls across 5 European countries using accelerometers: An observational study within the ENERGY-Project. Int J Behav Nutr Phys Act. 2012;9:34-41.

10. European Comission. Special Eurobarometer 412. Sport and physical activity. Report, 2014. [Acesso em 2018, Maio, 17]. Disponível em:http://ec.europa.eu/public_opinion/archives/ebs/ebs_412_en.pdf

11. Craggs C, Corder K, van Sluijs EM, Griffin SJ. Determinants of change in physical activity in children and adolescents: A systematic review. Am J Prev Med. 2011;40(6):645-58.

12. Djordjević-Nikić M, Dopsaj M, Vesković A. Nutritional and physical activity behaviours and habits in adolescent population of Belgrade. Vojnosanit Pregl. 2013;70(6):548-54.

13. Ostachowska-Gasior A, Piwowar M, Kwiatkowski J, Kasperczyk J, Skop-Lewandowska A. Breakfast and other meal consumption in adolescents from Southern Poland. Int J Environ Res Public Health. 2016;13(5):453-62.

14. Alexander D, Rigby MJ, Di Mattia P, Zscheppang A. Challenges in finding and measuring behavioural determinants of childhood obesity in Europe. Z Gesundh Wiss. 2015;23(2):87-94.

15. Villanueva R, Albaladejo R, Astasio P, Ortega P, Santos J, Regidor E. Socio-economic environment, area facilities and obesity and physical inactivity among children. Eur J Public Health. 2016;26(2):267-71.
16. International Physical Activity Questionnaire. [Internet]. IPAQ; 2010. [Access in2015 out 10].Available in: www.sites.google.com/site/theipaq/questionnaire_links

17. Jovanović R. Health aspects of investigations on adolescents' physical activity (In Serbian). M. Sc. Thesis. Faculty of medicine University of Nišs, Niš:2010.

18. Gelander L. Children's growth: a health indicator and a diagnostic tool. Acta Paediatr. 2006;95(5):517-8.

19. Bergier B, Bergier J, Paprzycki P. Level and determinants of physical activity among school adolescents in Poland. Ann Agric Environ Med. 2014;21(1):75-8.

20. Bergier B, Tsos A, Bergier J. Factors determining physical activity of Ukrainian students. Ann Agric Environ Med. 2014;21(3):613-6

21. Bergier B, Bergier J, Wojtyła A. Various aspects of physical activity among Lithuanian adolescents. Ann Agric Environ Med. 2012;19(4):775-9.

22. Dumith SC, Gigante DP, Domingue MR,Kohl HW. Physical activity change during adolescence: a systematic review and a pooled analysis.Int J Epidemiol 2011;40(3):685-98.

23. Verloigne M, Loyen A, Van Hecke L, Lakerveld J, Hendriksen I, De Bourdheaudhuij I. et al. Variation in population levels of sedentary time in European children and adolescents according to cross-European studies: a systematic literature review within DEDIPAC. Int J Behav Nutr Phys Act. 2016;13:70-91.

24. Marsaux CF, Celis-Morales C, Hoonhout J, Claassen A, Goris A, Forster H. et al.ObjectivelyMeasured Physical Activity in European Adults: cross-sectional findings from the Food4Me study.PLoS One. 2016;11(3):e0150902.

25. Viciana J, Mayorga-Vega D, Martínez-Baena A. Moderate-to-vigorous physical activity levels in physical education, school recess, and after-school time: influence of gender, age, and weight status.J Phys Act Health. 2016;13(10):1117-23.

26. Sallis JF, Zakarian JM, Hovell MF, Hofstetter CR. Ethnic, socioeconomic, and sex differences in physical activity among adolescents. J Clin Epidemiol.1996;49(2):125-34.

27. Vašíčková J, Groffik D, Frömel K, Chmelík F, WasowiczW. Determining gender differences in adolescent physical activity levels using IPAQ long form and pedometers. Ann Agric Environ Med. 2013;20(4):749-55.

28. Armstrong N,Welsman JR. The physical activity patterns of European youth with reference to methods of assessment.Sports Med.2006;36(12):1067-86.

29. Sukys S, Majauskienè D, Cesnaitiene VJ, Karanauskiene D.Do parents' exercise habits predict 13-18-year-old adolescents' involvement in sport? J Sports Sci Med. 2014;13(3):522-8.

30. Cheng LA, Mendonça G, Farias Júnior JC. Physical activity in adolescents: analysis of the social influence of parents and friends. J Pediatr (Rio J). 2014;90(1):35-41. 